Ann. Zootech., I974, 23 (4), 48I-489.

\title{
A PROPOSAL FOR A CONSTANTLY ROTATING CAROUSEL FOR SHEEP MILKING
}

\author{
M. MORAG (1), R. SAGI*, E. RUBIN**, Y. ARNON* \\ and M. LEVY* ${ }^{(1)}$ \\ Negev Institute for Arid Zone Research, \\ Beer Sheva, Israel \\ * Faculty of Agricultural Engincering, Technion, \\ Haifa, Isvael \\ ** Department of Biology, University of the Negev, \\ Beer Sheva, Israel
}

\section{SUMMARY}

A proposal for sheep milking using a constantly rotating carousel is outlined. The system is operated by a single milker. The only operation carried out by hand is teat cup application. All other operations (ewe entry, feeding, cup removal, teat spraying, ewe exit, cleaning of the machine, milk recording, etc.) are activated by the rotation of the carousel. Details of design and estimated performance are given. The system incorporates a milking machine capable of removing the total yield without machine stripping. Such a machine is, however, not yet available. The inadequacy of existing sheep milking machines in this respect is described and an interim design incorporating these inefficient machines in a semi-automated system is proposed.

\section{I. - INTRODUCTION}

Only a very small proportion of the world's dairy ewes are milked by machine; this proportion is, however, increasing rapidly (BOSC, PEPIN and OJEDA, I97I). The first sheep milking machine was developed in 1932 in Roquefort by Robert FLEURI (GALTIER, I943). The early machines were invariably installed in existing sheep housing. The first specially constructed parlours for sheep milking were built

(1) Dr M. Morag and Mr M. Levy deceased (I973) prior to the presentation of this paper. 
towards the end of the fifties. Modern ewe milking parlours are basically of two types: carousels and abreast systems. The former type, which was developed in Israel, consists of a circular milking platform which rotates so that sections of the perimeter passes an operator's pit where the milking equipment is situated. The ewes stand on the platform facing the centre of the carousel, and are held in position by yokes at a circular feeding trough situated about $90 \mathrm{~cm}$ from the perimeter. Ewes enter the carousel while it is stationary and are yoked into position. The carousel is then rotated to bring a batch of ewes opposite the operator's pit for milking. After the milking is completed the carousel is again rotated to bring a further batch of ewes into the milking position. Different sizes and models have been built. The largest models have a holding capacity as high as 240 head. Carousels have been described by Sharav (I962); Yalan et al. (I969) and by Bosc, PePin and OJEDA (I97I). The abreast system which was developed during the sixties is similar to the herring-bone parlours used for milking cows, except that in a sheep parlour the ewes stand at right angles to the operator's pit. This is because sheep are conveniently milked from behind through the back legs. Various systems of ewe flow into and out of the parlour have been devised. Different models have been described by Sharav (I962); Bosc (I963); Morag, Gibb and Fox (I967) ; Yalan et al. (1969) and by Bosc (I97I). Over the last decade most new installations have been of the abreast type (BOSC, PEPIN and OJEDA, I97I). It is believed that the investment needed for a carousel is higher because of the relatively large building required to contain the large circular milking platforms. No comparative cost study, either of investment or of running has, in fact, been published.

The recent introduction of constantly rotating compact carousels for milking cows (WhitTLESTONE, I970) has prompted this study into the feasibility of adapting such or a similar system for the milking of sheep. In a constantly rotating carousel system the animals enter, are milked and leave the parlour whilst the carousel is in constant rotation. This enables the number of animals milked per unit of time to be greatly increased. This new approach toward rotary milking parlours for sheep, has already brought about an interesting system which was introduced in France by DouzIEch, (I97I) under the trade name, Rotostalle. However, the system is, in fact, a group milking parlour. The animals mount the platform one by one, but then are treated as a group, $i . e$, for a period of time the platform is occupied by the same animals. Thus, in many respects, it is similar to the "Start-Stop " carousels described above, except that it rotates.

The system which is proposed here differs from the Rotostalle in that the animals are treated as individuals. There is a continuous movement of animals to and from the parlour, and the whole process of milking is completed through one turn of the platform. In a constantly rotating milking system for sheep, it is possible to have the animals facing either inward or outward. Each of the possibilities has its advantages and drawbacks. The biggest advantage of an outward facing system is, perhaps, the fact that the operator stands at the center of the installation and thus has the possibility of supervising the milking process more easily. This advantage can be fully utilized only if free access to any one of the milking units at any given time is ensured. Otherwise, the facing inward system which is more simple from a mechanical point of view might present a better solution. 


\section{II. - MATERIAL}

\section{A. - General form of the proposed system}

The proposed system, which is of the outward facing type, is schematically shown in figure I. Ewes enter the parlour from a collecting yard through a race over the carousel and at station (I) walk onto the rotating carousel platform. As

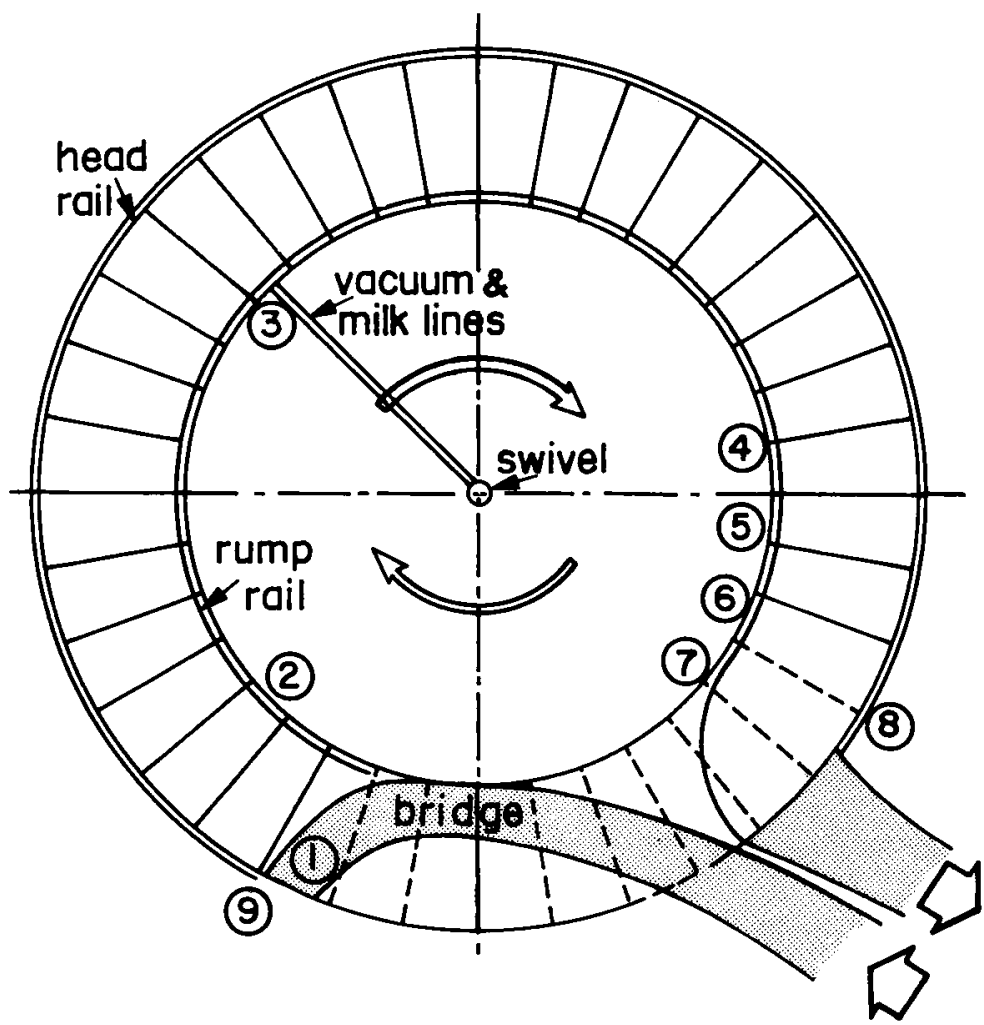

FIG. I. - General layout of constantly rotating carousel showing ewe pens

Carousel stations (see text) are indicated by circled numbers

Fig. I. - Disposition générale d'un carrousel à rotation continue montrant les stalles à brebis

Les numéros des stalles, caractéristiques décrites dans le texte, sont indiqués par un numéro entouré d'un cercle

each ewe approaches the rotating carousel she is presented with an empty pen into which she is lured by food in the trough. The ewe is constrained in the pen by a head rail, a trough and a rump rail (fig. 2). At station (2) the operator applies the teat cups to each ewe as she passes. Suspended under each pen is a set of teat cups and a milk holder. This low line equipment is mounted on circular vacuum and milk manifold pipes attached to the underside of the rotating carousel platform. 
At one point vacuum and milk lines rise and run to swivel manifold which is fixed to the ceiling over the centre of the carousel [station (3)]. When milking is completed the teat cups are removed automatically by an arm suspended from the rump rail and are returned to their original position suspended under the rotating platform of the carousel. The teat cup removal operation takes place at station (5). After the removal of the cups the teats are sprayed from below at station (6). The pen

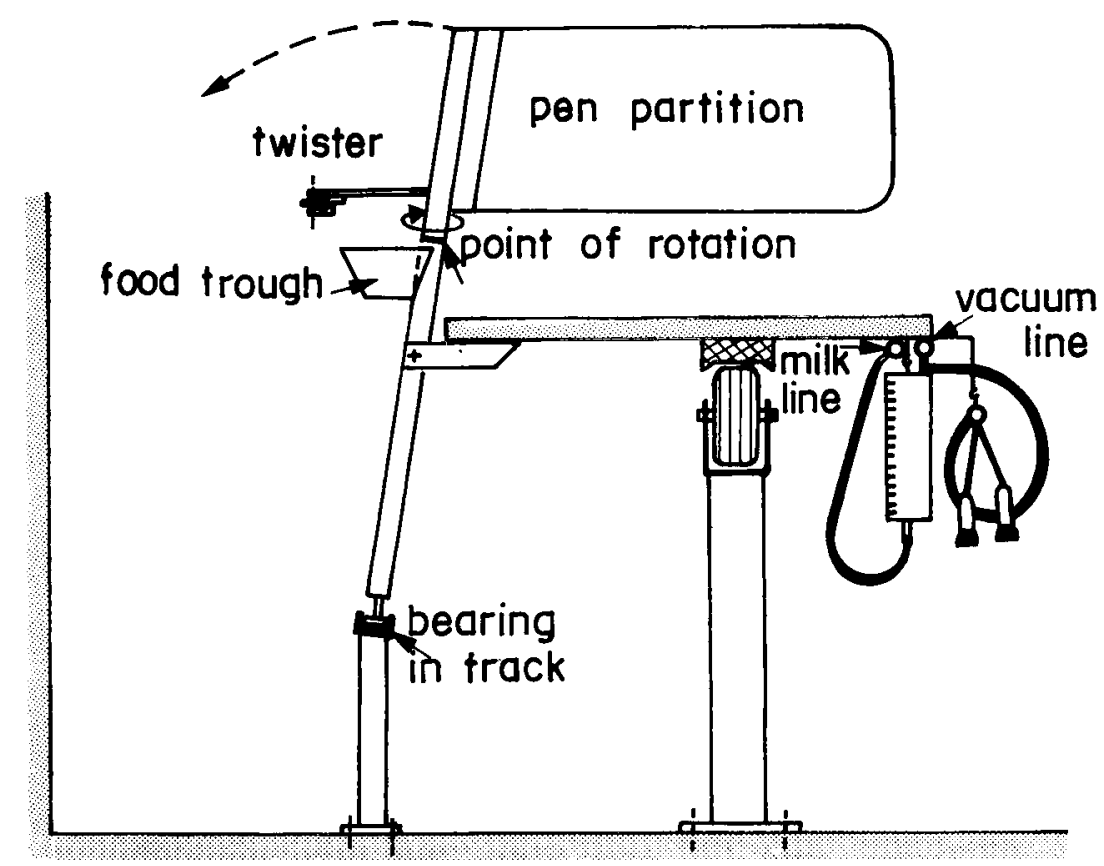

Fig. 2. - The mechanism for the lowering, raising and turning of the pen partitions and trough

Fig. 2. - Mécanisme pour l'abaissement,

l'élévation et la rotation des êléments de stalle et de l'auge à aliment

partitions then rise and the rump rail intrudes into the pen pushing the ewe off the carousel istation (7)]. During the portion of the cycle when the teat cups are suspended beneath the rotating platform [stations (7) to (I)] they are drawn through a series of baths for cleaning and pasteurisation in preparation for the new cycle. At station (8) the pen partitions are folded down to pass under the exit and entrance ramps. At station (9) they fold back into the upright position.

\section{B. - Design criteria}

The dimensions of the suggested carousel were calculated on the basis of the following criteria.

(i) Maximum milking time for dairy ewes of the Improved Awassi breed and its crosses is I2O seconds (SAGI and Morag, unpublished data). This time accomodates the milk flow of even the highest yielding and the slowest milking ewes. Most ewes are milked in far less time. 
(ii) Ewe entry time is estimated by one ewe per 5 seconds.

(iii) Teat cup application time; we believe that the routine work associated with teat cup application could be accomplished in 5 to Io seconds.

(iv) Pen width allowed per ewe is $35 \mathrm{~cm}$. This is wider than is usual in conventional carousels where the ewes are packed more tightly, one every 25 to $30 \mathrm{~cm}$. The present design allows even the largest (Improved Awassi and East Friesian) ewes easy entry into the pens.

(v) The number of pens is determined by the formula:

$$
\begin{gathered}
\text { Number of pens required } \\
\text { for ewe entry and exit } \\
\text { (non-milking phase) }
\end{gathered}+\frac{\text { Milk time }}{\text { Teat cup application time }}
$$

Our estimate of the maximum dead space that might be required for ewe entry and exit is about I2 pens. The value of the second term varies with milking time and the desired throughput. In the context of the figures given above $(i)$ and (iii) one requires between I2 (for ro seconds routine work) and 24 milking units giving a carousel size of between 24 and 36 pens. Shorter milking times and slower routines make for smaller carousels, whilst longer milking times and faster routines make for larger carousels. For the purpose of this theoretical presentation we have taken a 36 pen carousel.

(vi) The size of the carousel and building. The internal circumference of the 36 pen carousel is $\mathrm{I} 260 \mathrm{~cm}(36$ pens $\times 35 \mathrm{~cm} /$ pen). The internal diameter is $40 \mathrm{rm}$. Allowing for a platform $100 \mathrm{~cm}$ wide the external diameter is $60 \mathrm{Im}$. The roof area required to house this parlour need not be larger than $5^{\circ}$ square metres. The corresponding figures for a 24 pen carousel are : internal circumference $840 \mathrm{~cm}$; internal diameter $267 \mathrm{~cm}$; external diameter $467 \mathrm{~cm}$; roof area not more than 40 square metres.

(vii) The theoretical throughput, is a function of the routine work time (SAGI and MERRILL, I973). Consequently, the theoretical throughputs of the 24 and 36 stall carousels are 360 and 720 ewes per hour respectively. The throughput per man hour depends on the level of automation and the number of operators (see next chapter).

\section{C. - The milking machine and the milking operation}

In the proposed system the teat cups are applied by the operator and are removed by a stationary arm some 120 seconds later. With this arrangement there is a danger of ' overmilking' a fast milking ewe. To avoid this possible danger a flow controlled automatic removal device can be incorporated. The signal for the removal of the teatcups would originate from a flow rate metering device. Many dairy sheep exhibit a double milk ejection with two peaks of milk flow (LABUSSIERE, I969). However, the lag between the first and second milk flows is usually not longer than $5-8$ seconds. Hence, the response to the signal should therefore be slightly delayed to accomodate such ' two peak ' ewes. Alternatively overmilking could be avoided by adjusting the machine-on time to the milking time of the ewe. This can be done by milking groups of ewes which have similar machine milking times. The adjustment in machine-on time can be made either by applying the teat cups later or by removing 
them earlier in the cycle. The teat cup removal arm can be positioned as required. The adjustment of the machine-on time is a cheaper way of avoiding overmilking than the installation of a flow control system, but it requires the grouping of the ewes prior to milking.

The design assumes that the milking machine incorporated in the system is capable of removing all the milk yield without the aid of udder massage or of machine stripping. Although such machines are available for cows no such equipment has yet been developed for sheep. With the machines presently available a large proportion (30-60 p. 100) of the milk obtained by machine milking can only be removed from the udder when massage and machine stripping are carried out. This has been shown in Prealpes ewes (RICORdeau and Denamur, 1962) and also in high yielding Awassi and Awassi $\times$ East Friesian ewes (SAGI and MORAG, I974).

The development of an efficient milking machine, which removes the total yield without manual assistance, would enable the milking to be carried out by a single operator as set out in this proposal.

For the time being we envisage an interim semi-automated system incorporating existing (inefficient) milking machines. This would necessitate one or two additional operators to carry out udder massage and machine stripping. They would be positioned side by side at the end of the milking phase (fig. I, station 5). Fach ewe would be stripped by each operator for 4 or 5 seconds as she passes.

\section{D. - Eve traffic}

In conventional carousel systems the ewes are let into the parlour and mount the stationary platform. They thrust their heads through the yokes into the food trough. Sheep have to be manhandled to fill the empty yokes. When all the yokes are occupied they are closed section by section. After milking the yokes are opened and the ewes leave the platform and the parlour. The time spent by ewes in a conventional parlour can be as long as 20 minutes (YALAN et al., I969). These relatively long periods enable concentrate rationing to be carried out in the milking parlour.

The constantly rotating carousel with individual ewe pens (fig. 2) eliminates the following steps which are integral parts of the routine of the conventional carousel : i) stopping the carousel for ewe loading, ii) manhandling of ewes, iii) closing of yokes, $i v$ ) rotating batches of ewes to the milking pit and v) opening of yokes to release the ewes. Preliminary studies show that no serious problems are encountered in having ewes mount and dismount a moving platform. Entry into the race would be from an automatically operated collecting yard outside the parlour (WHITTLESTONE, I970).

A temporary interruption of sheep traffic in the race will not interrupt the continuity of milking. Empty pens are ignored by the operator. In a conventional system where the ewes are restrained only by yokes, unfilled places at the trough allow the adjacent ewes to move sideways and cause the teat cups to fall. Individual pens eliminate both the necessity for manhandling and reduce the danger of cups falling off the teats.

The time spent by a ewe at the food trough in the constantly rotating carousel is just over r2o seconds. In an intensive feeding system additional concentrate food may have to be offered elsewhere. 


\section{E. - Other operations}

The constant rotation of the carousel is utilized to activate certain automatic functions during the milking cycle, such as cup removal, the teat spray and the raising and lowering of pen partitions.

Figure 2 shows the pen partition and food trough. The sketches show a mechanism, activitated by carousel rotation for lowering, raising and turning the partitions. Each partition is free to rotate in a vertical and in a horizontal plane. The trough is free to swing only in a horizontal plane. The pen partitions and troughs are folded under the rack carrying the ewes entering the parlour. At the point of ewe entry the partition is upright. It is turned as to give a wide pen entry space allowing the ewe to enter the moving pen. As soon as the ewe is in the pen, the partition closes onto the side of the animal so that the internal pen width is not more than $35 \mathrm{~cm}$. The mechanism can be operated by a cam and follower mounted on a ring concentric with the carousel platform or alternatively by pneumatic cylinder operated from the vacuum manifold. The trough would be filled automatically at a point prior to ewe entry.

The disinfection of teats after milking is established practice in hygienic systems of cow milking and is believed to be an effective method of mastitis control (NEAVE, Dodd and KingweliL, I966; WeFen and Schulitz, I970). Whilst no evidence has yet been published on the effectiveness of the practice in sheep, any new system should at least include the possibility of disinfecting teats after milking. Figure 3 shows a possible mechanism for automatic teat spraying. Fixed, indivi-

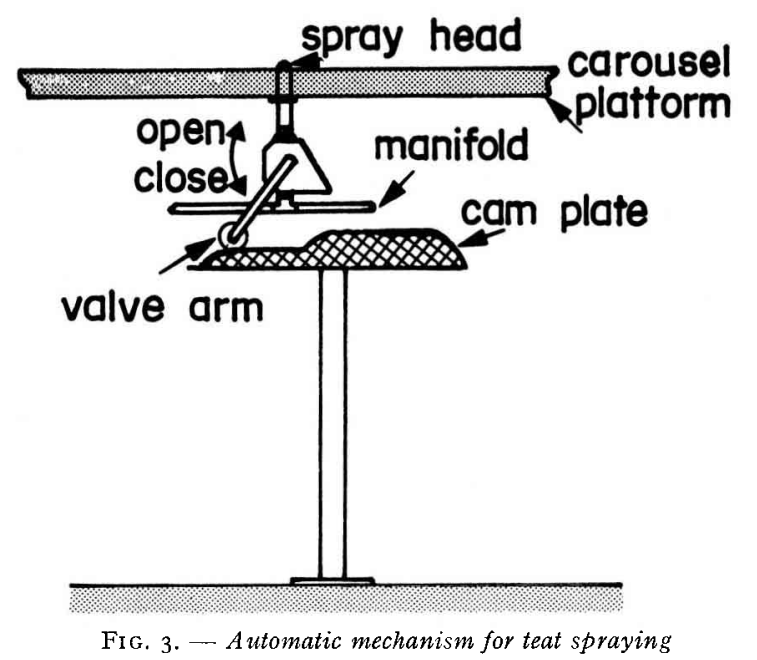

FIG. 3. - Mécanisme automatique pour la vaporisation des trayons

dually valved spray heads are mounted flush with the floor of the carousel platform in each pen. The head is activated when rotation of the carousel brings the valve arm into contact with a fixed cam plate. The valve is opened in two stages : at first 
only partially so as to clear the nozzle of feces and dirt and then at full force to spray the teats.

The spraying of teats presents no husbandry problems in flocks in which the ewes are weaned from their lambs at birth (MORAG, RAZ and EyAL, I970). In most dairy flocks, however, milking is followed by lamb suckling during at least the first two or three months of lactation (Folman, Volcani and Eyar, I966). One would have to check if the spray has any deleterious effect on the lambs and if so, teat disinfection would have to be carried out elsewhere after suckling.

\section{III. - CONCLUSIONS}

This proposal sets out the feasibility of automating the milking of dairy sheep. The full exploitation of the proposal will be possible when an efficient sheep milking machine, capable of removing all the yield without the intervention of the operator, is developed. In the meantime, a less efficient, semi-automatic system is envisaged.

The proposed system is of particular relevance in an advanced farming system with large scale operations, intensive management and high yielding ewes. In such a situation the price and availability of skilled dairy shepherds is often critical to the enterprise. It is no less important to the small holder in a family farm who has to limit the size of his flock because of his inability to milk large numbers of animals without assistance.

In addition to the low labour requirements and high performance the system offers a hygienic miiking routine for mastitis control and has low space and building requirements.

The automation of any livestock enterprise demands a high degree of management and of husbandry skill. The contact between shepherd and ewe is reduced to a minimum. In such a system there is a need for regular disease control measures (e.g., periodical mastitis checks, etc.) and general animal supervision.

Reçu pour publication en juin 1974 .

\section{ACKNOWLEDGEMENTS}

We are particularly grateful to Dr K-H. Finger and R. F. FELdMand for their generous help, encouragement and cooperation in the development of the ideas in this paper.

\section{RÉSUMÉ}

PROJE'T DE TRAITE DES BREBIS

A L'AIDE D'UN CARROUSEL A ROTATION CON'TINUE

Un système de traite des brebis à l'aide d'un carrousel à rotation continue est décrit. Le fonctionnement de l'installation est assuré par une seule personne. L'unique opération manuelle est celle de la pose des gobelets. Toutes les autres opérations (entrée des brebis, alimentation, 
retrait des gobelets, vaporisation des trayons, sortie des brebis, nettoyage de la machine, contrôle laitier, etc.) sont déclenchées par la rotation du carrousel. On donne les détails de l'installation et les performances estimées. Le système prévoit l'incorporation d'une machine à traire permettant l'extraction totale du lait sans égouttage mécanique. Cependant, une telle machine n'existe pas encore pour la traite des brebis. On décrit l'imperfection des machines actuelles utilisées et l'auteur propose une installation provisoire utilisant ces machines dans un système semi-automatique.

\section{REFERENCES}

Bosc J., I963. Problèmes de l'organisation du travail dans un troupeau de brebis laitières. Adaptation de la méthode arête de poisșon à la traite mécanique des brebis. Mecanisation et automation en Élevage, (6), I.39 (A. F. Z.).

Bosc J., I971. La traite mécanique des brebis laitières. La France agricole, 27 (n ${ }^{\circ}$ I340) 59-63.

Bosc J., Pepin J., OJeda E., r97i. Le développement de la traite mécanique des brebis laitières. Seminaire F. I. L. sur les laits autres que de Vache, Madrid, avril I97I, 20 p.

Douziech P. I97I., Schéma du Rotostalle. Nonveau système pour la traite automatique des brebis laitières. Rodez, I97I. Docliment ronéotypé.

Folman Y., Volcani R., Eyal E., I966. Mother-offspring relationships in Awassi sheep. I. The effect of different suckling regimes, and time of weaning on the lactation curve and milk yield in dairy flocks. J. Agric. Sc., Camb., 67, 37I-6.

Galtier L., 1943. La traite des brebis. Thèse de médecine vétérinaire (E. N. V. Lyon) Faculté de Médecine et Pharmacie de Lyon, $167 \mathrm{p}$.

LABUSSière J., I969. Importance, composition et signification des différentes fractions de lait obtenues successivement au cours de la traite mécanique des brebis. Ann. Zootech., 18, I85-196.

Morag M., Raz A., EYal E., I97o. Mother-offspring relationships in Awassi sheep. IV. The effect of weaning at birth, or after 15 weeks, on lactational performance in the dairy ewe. J. Agric. Sci., Camb., $75,183-7$.

Morag M., Gibb J. A. C., Fox S., I967. A milking parlour for experimental work with lactating ewes. J. Dairy Res, 34, 2I5-2I9.

Neave F. K., Dodd F. H., Kingwell R. G., 1966. A method of controlling udder disease. Vet. Rec., 78, 52I-3.

Ricordeau G., Denamur R., 1962. Production laitière des brebis Préalpes $d u$ Sud pendant les phases d'allaitement, de sevrage et de traite. Ann. Zootech., 11, 5-38.

SAGI R., MoraG M., I974. Udder conformation, milk yield and milk fractionation in the dairy ewe. Ann. Zootech., 23, I85-192.

SAGI R., MERRILL W. G., I973. Theoretical throughput capacities of large fixed and rotary Herringbone milking parlours (Submitted for publication).

Sharav E., 1962. Mechanical milking of sheep. Agricultural Yearbook, p. 473-88. Tel Aviv. Sifriath Hassadeh. (In Hebrew).

WeFEN D. P., Schultz L. H., Ig7o. Effectiveness of a post-milking teat dip in preventing new udder infection. J. Dairy Sci., 53, 1 $391-403$.

Whittlestone W. G., rg7o. The evolution of the modern cowshed. In the Proceedings of the New Zealand School and Conference on Machine Milking. 2. Mechanical Milking. Hamilton, New Zealand, 1969. The University of A uckland, p. 13-28.

Yalan E., Friedman J., Sharav E., Arnon Y., Brill U., Kofman U., ig69. (Sheep Milking Parlours) Interim report. Haifa : Technion Institute for Research and Development, Rural Building Research Center, Publication No 73. (In Hebrew). 